Robert A. Gross, MD, PhD, FAAN

Editor-in-Chief, Neurology ${ }^{\circledR}$

\section{Radiosurgery for unruptured cerebral arteriovenous} malformations: Long-term seizure outcome

One hundred sixty-one consecutive patients who underwent radiosurgery for unruptured arteriovenous malformations (AVM) were assessed up to 89.8 months. Of the 86 patients with a history of seizure before radiosurgery, $76.7 \%$ were seizure-free and $58.1 \%$ were medication-free. Although radiosurgery tends to cause seizures temporarily, it may improve seizure outcomes in patients with AVM-related seizures, especially in patients with AVM obliteration.

See p. 1292; Editorial, p. 1286

\section{MRI as diagnostic tool in early-onset peroxisomal disorders}

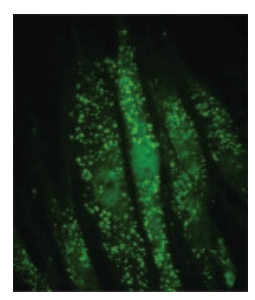

The authors collected clinical data and scored available MRIs of 6 patients with unclassified leukoencephalopathies.

Zellweger spectrum disorder was confirmed in 3 patients and D-bifunctional protein deficiency in the others.

Therefore, MRI reveals abnormalities suggestive of infantile onset peroxisomal defects; negative peroxisomal blood tests do not exclude the diagnosis.

See p. 1304; Editorial, p. 1288

Increased muscle expression of interleukin-17 in Duchenne muscular dystrophy

Expression levels of IL-17, Foxp3, TNF- $\alpha$, MCP-1, IL-6, and TGF- $\beta$ were analyzed in muscle biopsies from patients with Duchenne muscular dystrophy (DMD) and juvenile dermatomyositis. The association of IL-17 expression with levels of other inflammatory cytokines and with the clinical course of DMD suggests a possible pathogenic role of IL-17. See p. 1309

Total daily physical activity and the risk of $A D$ and cognitive decline in older adults $P$ t

Total daily exercise and nonexercise physical activity was measured continuously for up to 10 days with actigraphy from 716 older individuals without dementia. A higher level of total daily physical activity was associated with a reduced risk of Alzheimer disease.

See p. 1323
From editorialists Beeri \& Middleton: "In a world that is becoming progressively sedentary, and in the context of very limited success of the currently available medications to treat or delay $A D$, physical activity provides a promising, low-cost, easily accessible, and side-effect-free means to prevent $A D$." See p. 1290

\section{GLOBAL PERSPECTIVES}

Worldwide status of clinical experimentation with stem cells in neurologic diseases

This paper presents the state-of-the-art of the worldwide experience with stem cells in neurologic diseases and summarizes ongoing clinical trials. Breakthroughs and advances in clinical implementation are described, along with the pitfalls of the expanding "stem cell medical tourism."

See p. 1334

\section{SPECIAL ARTICLES}

Evidence-based guideline update: Pharmacologic treatment for episodic migraine prevention in adults 0 메 슷

This guideline found that antiepileptic drugs and $\beta$-blockers established as effective treatments for migraine prevention should be offered. The antidepressants amitriptyline and venlafaxine were also effective and should be considered for migraine prevention.

See p. $1337 \&$ p. 1346

Evidence-based guideline update: NSAIDs and other complementary treatments for episodic migraine prevention in adults $0 \mathbb{B}$ 会

Many nonstandard prescription, NSAID, and OTC medications are used for migraine, but evidence for migraine prevention varies. This guideline identifies 15 Class I-II studies with these drugs and assesses their efficacy for migraine prevention.

See p. $1346 \&$ p. 1337

NB: Editorial: “The Neurology ${ }^{\circledR}$ Resident \& Fellow Section: 2004-2012," see p. 1284. To check out this section, point your browser to www.neurology.org and click on the link to the Resident \& Fellow Section. 


\section{Neurology}

Spotlight on the April 24 Issue

Robert A. Gross

Neurology 2012;78;1283

DOI 10.1212/WNL.0b013e318254fb60

\section{This information is current as of April 23, 2012}

\section{Updated Information \&} Services

Permissions \& Licensing

Reprints including high resolution figures, can be found at: http://n.neurology.org/content/78/17/1283.full

Information about reproducing this article in parts (figures,tables) or in its entirety can be found online at:

http://www.neurology.org/about/about_the_journal\#permissions

Information about ordering reprints can be found online:

http://n.neurology.org/subscribers/advertise

Neurology ${ }^{\circledR}$ is the official journal of the American Academy of Neurology. Published continuously since 1951, it is now a weekly with 48 issues per year. Copyright Copyright $@ 2012$ by AAN Enterprises, Inc.. All rights reserved. Print ISSN: 0028-3878. Online ISSN: 1526-632X.



